THURSDAY, FEBRUARY 24, I9Io.

\section{A TEXT-BOOK OF BOTANY.}

Varming-Johansen, Lehrbuch der algemeinen Botanik. Herausgegeben von Dr. E. Meinecke. Zweiter Theil (Schluss). Pp. iv $+48 \mathrm{I}-668$. (Berlin : Gebrüder Bornträger, I90g.) Price 4.80 marks.

DROF. WARMING'S book, the concluding part of which has recently been issued, will be received $x$ ith interest, whilst at the same time it cannot escape some criticism. But in the latter connection the circumstances of its publication must, in fairness to the author, be kept in mind. The first part was three years in the press, and even after its appearance an interval of two years elapsed before the second and final part was issued. Botanical thought has moved rapidly during the last decade, and any text-book must naturally suffer when produced under conditions so disadvantageous as those under which Prof. Warming's book has laboured.

The earlier chapters of the first volume contain a morphological treatment of the plant on interesting lines, the ecological factors due to physical environment, \&c., being kept well in sight. Many excellent figures are given, and examples are drawn from plants which are not always utilised in these matters as they might be in modern works. Some topics strike us as having been somewhat inadequately discussed, however, and especially that of phyllotaxis. If this subject is to be introduced at all (and it can hardly be omitted in a treatise such as this) one looks for more than a somewhat perfunctory account of the Braun-Schimper views.

The chapter on abstract morphology appears to us rather to miss fire-either it is too long, or it is not long, or philosophical, enough. The cell also ss treated perhaps somewhat dogmatically. This may be difficult to avoid in a treatise which, while aiming at being comprehensive, is limited in size. In any event, however, there is no excuse for the introduction of the old and long discredited figure of the lily cell showing large centrosomes. This figure is the more surprising since the author himself avows his disbelief in the centrosomes as there reproduced! The section dealing with the tissue systems is good; we would willingly have seen it enlarged. Many interesting observations are worked in with the general mass of information, and the whole is admirably handled and illustrated. The general classification of the tissue systems follows that employed by Haberlandt in his well-known treatise.

The structure of the wood is well described and figured, though the difficulties (e.g. sliding growth) presented by the differentiation of the elements are passed over. This is, however, evidently in keeping with the main plan which the author has kept before him, of making his book chiefly informational, rather than to introduce a discussion of the many doubtful and difficult problems. Similarly, the question as to NO. 2104 , VOL. 82] the mode of formation of annual rings only occupies a few lines.

The latter part of the first volume contains an account of the physiology of nutrition, transpiration, growth, and irritability. The matter is connected up with the life of plants in the open, and although there may be differences of opinion as to the validity of the author's views on some matters-e.g. the ascent of sap-everyone will probably admit that the subjectmatter is treated in an interesting way. This especially applies to the section on the regulation of functions.

The first part ends in the middle of an account of the reproductive structures, and this is continued in the second and final instalment of the work. The treatment is too short to enable anything like justice to be done to this important subject, the Florideæ, for example, being dismissed with rather less than a page of print.

The morphological discussion undoubtedly loses much on account of the omission of illustrations drawn from palæontological evidence; and, again, we find a figure $(476)$ of the germination of the pollen grain of Lilium showing centrosomes, while in the legend we read tha" he centrosomes are to be neglected." Why use such a figure when thare are others to choose from? Or, better still, why not draw a new one?

The chapter dealing with the life-history of the plant and its relation to external conditions is, as one would anticipate, one of the most interesting in the book, and the pages devoted to the consideration of the occurrence and significance of rhythm and of the resting periods of plants will be found to be very suggestive. Rhythm is indeed one of the most striking of physiological phenomena, and the resting period is one of its remarkable phases.

The volume ends with a brief account of the general questions which centre around heredity, variability, and such like problems. The examples are well chosen, and the student will find the discussion helpful.

The book as a whole compares well with many text-books that have appeared in recent years. It also shares some of their inevitable defects. The subject is really too large to be treated within limits of space which twenty years ago were reasonably adequate. An author who attempts to do so is bound to incur adverse criticism, and we have given, perhaps, a somewhat candid expression of our own opinion of the present work in what has gone before. But we do not intend to convey the impression that Prof. Warming has not ably discharged his task, so far as it was possible for anyone to do it.

The book is really stimulating in many ways; indeed, any work by Prof. Warming, who has done so much to initiate ecological work, could not fail in this respect; and so we leave it, passing lightly over what may be looked on as unavoidable imperfections, and congratulating the author on the chapters of his work in which he has achieved unquestioned succesa

J. B. F 